\title{
Metals and arsenic in marine fish commercialized in the NE Brazil: Risk to human health
}

\section{Carlos Alberto da Silva, Silvia de Oliveira Santos, Carlos Alexandre Borges Garcia, Gabriela Cugler de Pontes \& Julio Cesar Wasserman}

To cite this article: Carlos Alberto da Silva, Silvia de Oliveira Santos, Carlos Alexandre Borges Garcia, Gabriela Cugler de Pontes \& Julio Cesar Wasserman (2019): Metals and arsenic in marine fish commercialized in the NE Brazil: Risk to human health, Human and Ecological Risk Assessment: An International Journal, DOI: 10.1080/10807039.2018.1529552

To link to this article: https://doi.org/10.1080/10807039.2018.1529552

曲 Published online: 10 Jan 2019.

Submit your article to this journal

Щ Article views: 18

View Crossmark data ¿ 


\title{
Metals and arsenic in marine fish commercialized in the NE Brazil: Risk to human health
}

\author{
Carlos Alberto da Silva ${ }^{a}$, Silvia de Oliveira Santos ${ }^{\mathrm{b}}$, Carlos Alexandre Borges \\ Garciac $^{c}$, Gabriela Cugler de Pontes ${ }^{\mathrm{d}}$, and Julio Cesar Wasserman ${ }^{\mathrm{e}}$ \\ ${ }^{a}$ Embrapa Coastal Tablelands, Aracaju, Brazil; ${ }^{b}$ Federal University of Sergipe - FAPITEC, Aracaju, Brazil; \\ 'Department of Chemistry, Federal University of Sergipe (UFS), Aracaju, Brazil; ${ }^{\mathrm{d} D e p a r t m e n t ~ o f ~}$ \\ Geoenvironmental Analysis, University Federal Fluminense, Niterói, Brazil; ${ }^{~}$ Post-Graduation Programme \\ in Geochemistry, and Post-Graduation Programme in Sustainable Systems Management, University \\ Federal Fluminense, Av. Litorânea, Institute of Geosciences, Niterói, Brazil
}

\begin{abstract}
Arsenic, cadmium, lead, and mercury in fish is the result of longterm biomagnification in the food chain and is of public concern, due to the toxicity they engender. The objective of this research was to determine the concentrations of arsenic, cadmium, lead, and mercury in 13 species of marine fish broadly commercialized in Aracaju, $\mathrm{SE}$, Brazil and to evaluate the risks of fish consumption associated with these trace elements, using the Target Hazard Quotient (THQ). As, $\mathrm{Cd}$, and $\mathrm{Pb}$ levels were measured with inductively coupled plasma mass spectrometry (ICP-MS), and mercury was analyzed via cold vapor atomic absorption spectrometry. The results indicate a large variability in concentrations for arsenic $\left(0.07-2.03 \mathrm{mg} \mathrm{kg}^{-1}\right)$ and mercury $\left(0.01-1.44 \mathrm{mg} \mathrm{kg}^{-1}\right)$, associated with the animal dietary category. Cadmium $\left(0.04-0.19 \mathrm{mg} \mathrm{kg}^{-1}\right)$ and lead $\left(<0.01-0.45 \mathrm{mg} \mathrm{kg}^{-1}\right)$, on the other hand showed a mild variability. None of the evaluated specimens had $\mathrm{As}, \mathrm{Cd}$, and $\mathrm{Pb}$ THQ values higher than 1. The THQ values for mercury were higher but indicated no consumption risk, except for amberjack, and snook fish. Overall THQ indicates lower risk of consumption in fish that are at the base of the food chain, than in those that are top predators.
\end{abstract}

\section{ARTICLE HISTORY}

Received 3 September 2018

Revised manuscript

accepted 25 September 2018

\section{KEYWORDS}

toxicity; metals; target hazard quotient; marketed fish; maximum tolerance limits; health risk

\section{Introduction}

Fish meat is rich in essential amino acids, vitamins, micro- and macroelements, and ômega-3 long-chain polyunsaturated fatty acids such as docosahexaenoic acid and eicosapentaenoic acid, and is also low in cholesterol (Guil-Guerrero et al. 2011). These characteristics confer on fish meat the advantage of qualifying as one of the more healthful foods (Storelli 2008; Afonso et al. 2013; Farrugia et al. 2015); its consumption is beneficial for neurological growth and development, and it reduces the risk of stroke disease and the incidence of cardiovascular diseases, while also enhancing the human immune response (He 2009; Pohlenz and Gatlin 2014). In contrast to the dietary

CONTACT Julio Cesar Wasserman geowass@vm.uff.br $B$ Post-Graduation Programme in Geochemistry, and PostGraduation Programme in Sustainable Systems Management, University Federal Fluminense, Av. Litorânea, Institute of Geosciences, office 406, CEP 24210-346, Niterói, Brazil.

Color versions of one or more of the figures in the article can be found online at www.tandfonline.com/r/bher.

(C) 2019 Taylor \& Francis Group, LLC 


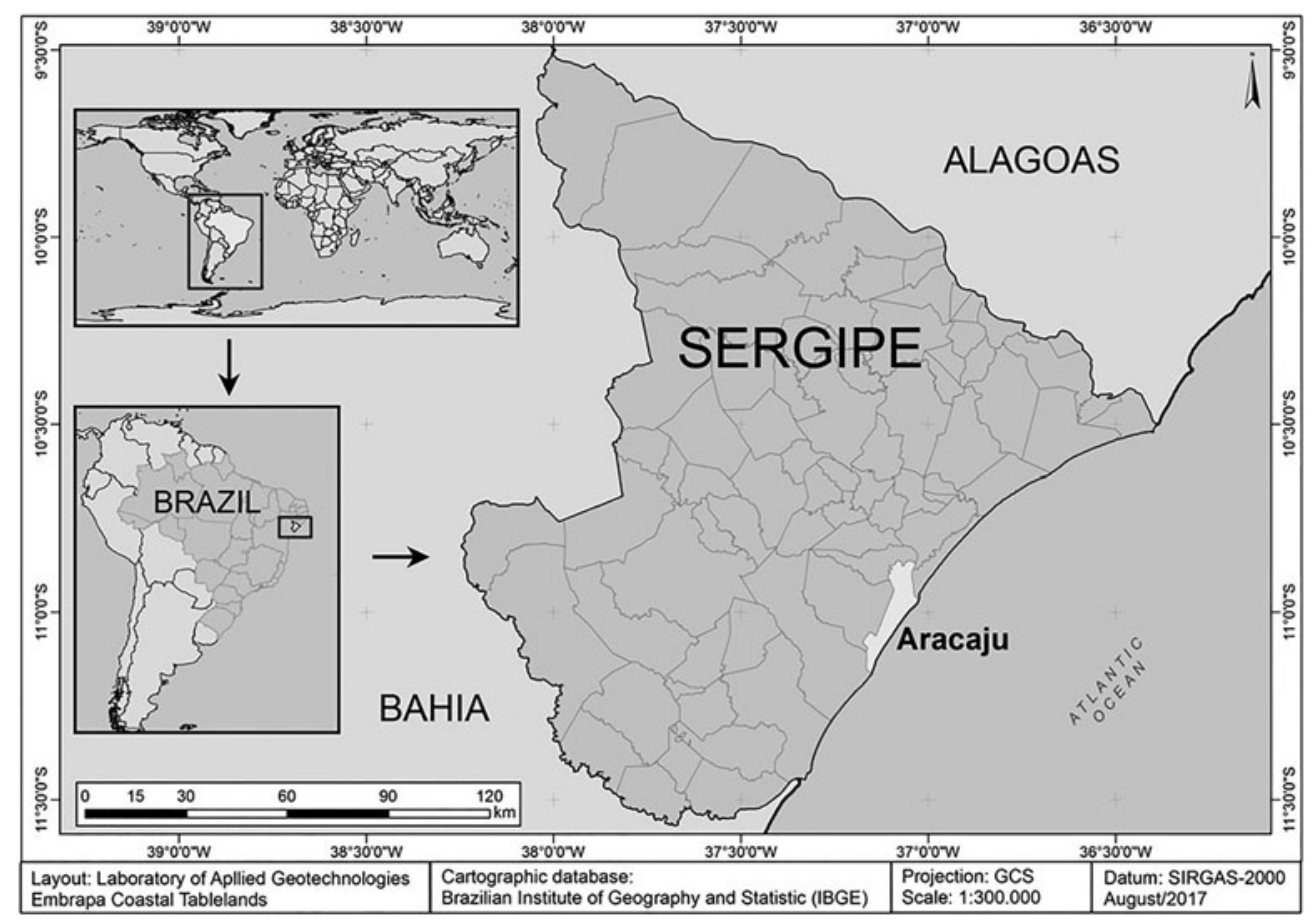

Figure 1. Study area. Location of the Municipality of Aracajú in the State of Sergipe, Brazil.

advantages of fish, however, the potential risk of exposure to chemical contaminants (and their derivatives) contained in fish must also be considered, when assessing the influence of this food on human health (Bosch et al. 2016). In fact, there has been an increasing reluctance to eat fish because of reports stating that its consumption can result in significant exposure to a variety of chemicals. Despite the uncertain risk/benefit tradeoff, demand for fish products is increasing worldwide while wild-caught landings remain stable (FAO 2016).

Trace metals stand out among chemical pollutants because of their ability to accumulate in the tissues of aquatic organisms and the consequent possibility of contaminating humans through the food chain (Castro-González and Méndez-Armenta 2008; Mathews and Fisher 2008, 2009, Guo et al. 2016; Schneider et al. 2018). The trace elements arsenic, cadmium, lead, and mercury present in fish meat at parts-per-million (ppm) levels are considered toxic, and can cause deleterious effects on human health (Rainbow 2007; Berk et al. 2014).

Fish containing concentrations higher than the background level of these trace elements have been measured by environmental protection agencies using risk assessment tools. The Target Hazard Quotient (THQ) estimation methodology for human health risk assessment was initially proposed by the United States Environmental Protection Agency in the 1980s (USEPA 1989). The THQ is based on the calculation of metal concentrations in food, intake rates, and the reference oral dose, and has been used in studies evaluating the potential risk of exposure to contaminants in vegetables (Yañez et al. 2018), vegetable oils (Zhu et al. 2011), oysters (Zhao et al. 2016), and fish (Yi et al. 2011; Adel et al. 2016; Avigliano et al. 2016; Gu et al. 2017). 
Because of the potential and/or real danger of consumption of fish with significant levels of toxic metals, many countries monitor the levels of these trace elements in fish locally consumed, to protect human health. In Brazil, the National Health Surveillance Agency (ANVISA) is responsible for the control of food contaminants through the Maximum Tolerance Limits (MTL) for inorganic contaminants, published in Resolution \# 42, dated August 29, 2013 (ANVISA 2013). The values of MTL for metals in fish and their products are: $1.00 \mathrm{mg} \mathrm{kg}^{-1}$ arsenic; $0.30 \mathrm{mg} \mathrm{kg}^{-1}$ lead; from 0.05 to $0.30 \mathrm{mg} \mathrm{kg}^{-1}$ cadmium, depending on the species; and $0.50 \mathrm{mg} \mathrm{kg}^{-1}$ mercury for non-carnivorous fish and $1.00 \mathrm{mg} \mathrm{kg}^{-1}$ mercury for carnivores.

However, surveillance of contaminant levels above the MTL prescribed by legislation is not sufficient to characterize the risk to human health, because fish intake rate and frequency of exposure to the contaminant are not considered in the MTL. Furthermore, consumers generally do not have enough information to make decisions about what kind of fish to eat, considering that they do not know how the levels of contaminants vary among fish.

Considering the risk of contamination in humans, through fish consumption, concentrations of arsenic, cadmium, lead, and mercury in 13 species of marine fish commercialized in Aracaju were determined and quantified and compared with the MTL prescribed by the Brazilian Legislation. The fish consumption risks associated with these trace elements was evaluated, using the Target Hazard Quotient tool.

\section{Material and methods}

\section{Sample collection and preservation}

The fish species to be evaluated were selected as a function of information from the Fisheries and Aquaculture Statistical Bulletin (Brasil 2011) and from a fish market study in Aracaju, Sergipe, Brazil (Anonymous 2004), as well as on their availability and purchase frequency among the general population.

Samples of 13 species of marine fish were randomly purchased at general-purpose markets, fish markets, street markets and/or supermarkets in Aracaju, Sergipe, northeastern Brazil (Figure 1), from March to April 2016, totaling 39 samples, with 3 samples per species. The classification, habitat, and dietary categories of these fish are shown in Table 1. The fish samples were transported refrigerated in thermal boxes to Embrapa Coastal Tablelands Laboratory in Aracaju, SE. Approximately 100-150 g of the lateraldorsal muscle of each fish were separated and lyophilized for $48 \mathrm{~h}$, until they reached constant weights. Afterwards, they were stored in a freezer at $-15^{\circ} \mathrm{C}$. Samples were ground in a processor and sieved through $250 \mu \mathrm{m}$ nylon mesh to obtain homogeneous samples. Between each milling the processor was washed with $10 \% \mathrm{v} / \mathrm{v}$ nitric acid solution and then with Milli-Q water $(18 \mu \Omega)$ to avoid cross-contamination between samples.

\section{Reagents and standard solutions}

All solutions were prepared with analytical-grade reagents, and the Milli-Q water $(18 \mu \Omega)$ was obtained from a Millipore ${ }^{\circledR}$ Simplicity®UV (Molsheim, France) purifier. 
Table 1. Classification, habitat, and dietary category of the studied fish species.

\begin{tabular}{|c|c|c|c|c|}
\hline Common name & Family & Scientific name & Habitat & Dietary category \\
\hline Amberjack & Carangidae & Seriola spp. & Demersal & Carnivorous \\
\hline Tuna fish & Scombridae & Thunnus spp. & Pelagic & Piscivorous \\
\hline Catfish & Ariidae & Bagre spp. & Demersal & $\begin{array}{l}\text { Benthic inverte- } \\
\text { brate feeder }\end{array}$ \\
\hline Dolphinfish & Coryphaenidae & Coryphaena hippurus & Pelagic & $\begin{array}{l}\text { Fish and inverte- } \\
\text { brate feeder }\end{array}$ \\
\hline Acoupa weakfish & Sciaenidae & Cynoscion acoupa & Demersal & $\begin{array}{l}\text { Fish and benthic inver- } \\
\text { tebrate feeder }\end{array}$ \\
\hline Weakfish & Sciaenidae & Cynoscion spp. & Demersal & $\begin{array}{l}\text { Fish and benthic inver- } \\
\text { tebrate feeder }\end{array}$ \\
\hline Sardine & Clupeidade & Sardinella brasiliensis & Pelagic & Planktivorous \\
\hline Mullet & Mugilidae & Mugil curema & Pelagic & Planktivorous \\
\hline Snapper fish & Lutjanidae & Lutjanus spp. & Demersal & Omnivorous \\
\hline Snook & Centropomidae & $\begin{array}{l}\text { Centropomus } \\
\text { undecimalis }\end{array}$ & Neritic & Piscivorous \\
\hline Cobia & Rachycentridae & Rachycentron canadum & $\begin{array}{l}\text { Benthic and } \\
\text { reef-associated }\end{array}$ & $\begin{array}{l}\text { Fish and benthic inver- } \\
\text { tebrate feeder }\end{array}$ \\
\hline Whitemouth croaker & Sciaenidae & Micropogonias furnieri & Neritic & $\begin{array}{l}\text { Benthic inverte- } \\
\text { brate feeder }\end{array}$ \\
\hline Grouper & Serranidae & $\begin{array}{l}\text { Mycteroperca } \\
\text { interstitialis }\end{array}$ & $\begin{array}{l}\text { Benthic and } \\
\text { reef-associated }\end{array}$ & Piscivorous \\
\hline
\end{tabular}

All materials used in the preparation and analysis of the samples were immersed in $10 \% \mathrm{v} / \mathrm{v} \mathrm{HNO}_{3}$ acid bath for $24 \mathrm{~h}$ and rinsed with Milli-Q $(<18 \mu \Omega)$ water prior to use. Standard stock solutions of As, Cd, $\mathrm{Pb}\left(100 \mathrm{mg} \mathrm{L}^{-1}\right)$, and $\mathrm{Hg}\left(1000 \mathrm{mg} \mathrm{L}^{-1}\right)$ SpecSol® (Jacareí, Brazil) were used in the preparation of the calibration standards.

\section{Sample digestion}

The metals contained in about 0.4-0.5 g (dry weight) of lyophilized triplicate samples of muscle were extracted in a closed microwave system Anton Paar, model Multiwave 3000 , at the maximum power of $1400 \mathrm{~W}$, in the four steps represented in Table 2. The extraction was carried out with $10 \mathrm{~mL}$ nitric acid $(7 \mathrm{M})$ and $2 \mathrm{~mL} 30 \% \mathrm{v} / \mathrm{v}$ hydrogen peroxide $\left(\mathrm{H}_{2} \mathrm{O}_{2}\right)$, according to methodology adapted from Jarić et al. (2011). After cooling to room temperature, the digested samples were brought to the volume of $100 \mathrm{~mL}$ with Milli-Q water $(<18 \mu \Omega)$ and stored at $4{ }^{\circ} \mathrm{C}$ until analysis.

For $\mathrm{Hg}$ analyses, triplicate $0.5 \mathrm{~g}$ of the sample were digested with $15 \mathrm{~mL} 1: 1$ solution of $\left(\mathrm{H}_{2} \mathrm{SO}_{4}+\mathrm{HNO}_{3}\right)$ in a kinetic reactor (cold finger), heated for $2 \mathrm{~h}$ in a $60{ }^{\circ} \mathrm{C}$ sand bath. After cooling, $3 \mathrm{~mL} \mathrm{H}_{2} \mathrm{O}_{2}, 52 \mathrm{~mL}$ deionized water, and $15 \mathrm{~mL} 5 \%$ potassium permanganate $\left(\mathrm{KMnO}_{4}\right)$ were added. The excess oxidant was then neutralized with $12 \%$ hydroxylamine hydrochloride (Hight and Cheng 2005), and $5 \mathrm{~mL}$ of the sample were placed in the reaction flask with $1 \mathrm{~mL}$ stannous chloride $\mathrm{SnCl}_{2}$ (20\%) (Hatch and Ott 1968).

\section{Detection methods and quality control}

An inductively coupled plasma mass spectrometer (ICP-MS, Thermo, Germany) was used for the quantitative determination of $\mathrm{As}, \mathrm{Cd}$, and $\mathrm{Pb}$. The instrumental parameters of ICP-MS were: radiofrequency applied power of $1.3 \mathrm{~kW}$, plasma gas flow rate of 
Table 2. Microwave digestion system operational parameters.

\begin{tabular}{lcccc}
\hline Step & Temperature $\left({ }^{\circ} \mathrm{C}\right)$ & Ramp $(\mathrm{min})$ & Hold $(\mathrm{min})$ & Fan level \\
\hline 1 & 100 & 13.0 & 7.0 & Slow \\
2 & 150 & 7.0 & 12.0 & Slow \\
3 & 180 & 6.0 & 10.0 & Slow \\
4 & 50 & & 30.0 & Fast \\
\hline
\end{tabular}

$13 \mathrm{~L} \mathrm{~min}^{-1}$, auxiliary gas flow rate of $0.7 \mathrm{~L} \mathrm{~min}^{-1}$, nebulizer gas flow rate of $0.87 \mathrm{~L} \mathrm{~min}{ }^{-1}$, peak jump scan mode, residence time of $10 \mathrm{~ms}$, and number of readings per replicate was equal to 3 . Reagent blanks were processed in the same manner as the samples and were read every ten sample batteries. Total mercury reading was carried out in a Lumex RA 915+ cold vapor atomic absorption spectrophotometer (CVAAS, with Zeeman correction, Russia).

The validation of the analytical method was done with reference material DORM-3 (fish protein certified reference material for trace metals-NRCC) and the recovery values of the analytes warranted the quality of the data.

\section{Risk assessment}

Mean concentrations of arsenic, cadmium, lead, and mercury were used for the estimation of the THQ. The formula used in the THQ calculation was proposed by the USEPA (1989) as Eq. (1):

$$
T H Q=(E F \times E D \times F I R \times C / R F D \times B W \times E T) \times 10^{-3}
$$

where $E F$ is exposure frequency (365 days year $^{-1}$ ); $E D$ is exposure duration (70 years), equivalent to the average human-life estimate; FIR is food intake rate (fish $=36 \mathrm{~g}_{\text {person }}{ }^{-1}$ day $^{-1}$, as suggested by USEPA (1989); $C$ is the metal concentration in the fish $\left(\mu \mathrm{g} \mathrm{g}^{-1}\right) ; R F D$ is the oral reference dose $\left(\right.$ As $=0.3 \times 10^{-3} \mu \mathrm{g} \mathrm{g}^{-1}$ day $^{-1}, \mathrm{Cd}$ $=1 \times 10^{-3} \mu \mathrm{g} \mathrm{g}^{-1} \mathrm{day}^{-1}, \mathrm{~Pb}=4 \times 10^{-3} \mu \mathrm{g} \mathrm{g}^{-1} \mathrm{day}^{-1}, \mathrm{Hg}=0.5 \times 10^{-3} \mu \mathrm{g} \mathrm{g}^{-1} \mathrm{day}^{-1}$ ) (Storelli 2008; USEPA 2010); BW is the mean adult body weight $(70 \mathrm{~kg}) ; E T$ is the noncancerous exposure time ( 365 days year $\left.{ }^{-1} \times \mathrm{ED}\right)$.

In the risk assessment, we assumed that the oral intake of the contaminant was equal to the dose absorbed by the human organism and that cooking the fish did not change the concentration or toxicity of the contaminant (USEPA 1989). If the calculated THQ is $<1$ there is no appreciable risk for a given pollutant; if the value of THQ is $>1$ there is an imminent risk to continuing to consume fish at that frequency (Storelli 2008).

\section{Results and discussion}

The precision and accuracy of the analytical method given by the recovery values of the analytes were within the range of $80-110 \%$, considered acceptable for trace metal analysis (Table 3).

The concentrations of metals in the fish samples are given in $\mathrm{mg} \mathrm{kg}^{-1}$ on a wet basis (Table 4) for comparison with values published on the same basis by the Brazilian Legislation. 
Table 3. Concentrations of arsenic, cadmium, lead, and mercury ( $\mathrm{mg} \mathrm{kg}^{-1}$ dry basis) in the reference material DORM$3(n=3)$.

\begin{tabular}{lccc}
\hline Element & Certified value $\left(\mathrm{mg} \mathrm{kg}^{-1}\right)$ & Measured value $\left(\mathrm{mg} \mathrm{kg}^{-1}\right)$ & Recovery $(\%)$ \\
\hline As & $6.88 \pm 0.30$ & $6.12 \pm 0.61$ & 88.95 \\
$\mathrm{Cd}$ & $0.29 \pm 0.02$ & $0.27 \pm 0.03$ & 93.10 \\
$\mathrm{~Pb}$ & $0.39 \pm 0.05$ & $0.39 \pm 0.08$ & 100.00 \\
$\mathrm{Hg}$ & $0.38 \pm 0.06$ & $0.39 \pm 0.01$ & 102.63 \\
\hline
\end{tabular}

\section{Arsenic}

The lowest and highest concentrations of total arsenic were $0.07 \mathrm{mg} \mathrm{kg}^{-1}$ in Cynoscion spp. and $2.03 \mathrm{mg} \mathrm{kg}^{-1}$ in $R$. canadum, respectively. The mean concentration in all fishes evaluated in this study was $0.69 \pm 0.31 \mathrm{mg} \mathrm{kg}^{-1}$, considerably lower than in fish of the Gulf of Mexico, averaging $4.23 \pm 9.39 \mathrm{mg} \mathrm{kg}^{-1}$ in the reference area and $7.33 \pm 14.25 \mathrm{mg} \mathrm{kg}^{-1}$ in the area impacted by pulp mill effluent (Lewis et al. 2002). Much higher concentrations were observed in the surroundings of an industrial complexes clustered along the coast in the central Adriatic Sea, where average of $41.17 \pm 7.49 \mathrm{mg} \mathrm{kg}^{-1}$ for fish was observed (Perugini et al. 2014). Jureša and Blanuša (2003) also found high arsenic levels in fish along the Croatian coast of the Adriatic Sea: ranging from 0.56 to $23.30 \mathrm{mg} \mathrm{kg}^{-1}$.

The concentrations range of As observed in this study was also lower than that found by Burger and Gochfeld (2005), which ranged from 0.23 to $3.30 \mathrm{mg} \mathrm{kg}^{-1}$ in marine fish, marketed in New Jersey, USA; $35 \%$ of those samples exceeded the maximum limit of $1.3 \mathrm{mg} \mathrm{kg}^{-1}$ prescribed by U.S. legislation (Fallah et al. 2011). In Brazil, a study conducted by the Food Technical Commission (CTA) in 2013 detected arsenic in samples of tuna fish, whitemouth croaker, and sardines marketed in São Paulo, SP, Brazil, with only $2.5 \%$ of the samples below the maximum tolerated values of $1.0 \mathrm{mg} \mathrm{kg}^{-1}$ set by Brazilian Legislation (CTA 2013). Medeiros et al. (2012) detected levels of total As between 0.002 and $11.800 \mathrm{mg} \mathrm{kg}^{-1}$ when analyzing fish commercialized in the main market of the city of Niterói, RJ, Brazil, whereas Silva et al. (2016) found between 0.48 and $1.19 \mathrm{mg} \mathrm{kg}^{-1}$ in fish commercialized in Salvador, BA, Brazil. In this study, guachanche barracuda (Sphyraena guachancho) and snapper fish (Lutjanus synagris) exceeded the maximum tolerable limit (MTL) of $1.0 \mathrm{mg} \mathrm{kg}^{-1}$ established by Brazilian Legislation. According to Burger and Gochfeld (2005), the comparison and interpretation of metal levels among commercial fish samples is difficult because their geographical origins are undetermined, and their diet may exhibit variations in both predation patterns and specificity. We believe that differences in the trace elements' content occurred because their accumulation in marine organisms is related not only to the presence of the pollutant, but also to a range of biological (species, age, growth stage) and environmental (temperature, geochemical anomalies, salinity) factors that influence incorporation processes (Burger et al. 2014). In American Samoa, the concentrations of total As in mullet (Mugil spp.) have ranged from 0.37 to $0.94 \mathrm{mg} \mathrm{kg}^{-1}$ (Peshut et al. 2008), while in the Black Sea concentrations ranged from 0.38 to $1.10 \mathrm{mg} \mathrm{kg} \mathrm{kg}^{-1}$ (Makedonski et al. 2017). Those values are higher than observed in this study for mullet (M. curema), which ranged from 0.15 to $0.18 \mathrm{mg} \mathrm{kg}^{-1}$.

The predatory tuna fish, snook, and cobia had mean levels of total arsenic above the maximum tolerable levels of $1.0 \mathrm{mg} \mathrm{kg}^{-1}$, and two species-catfish and whitemouth 


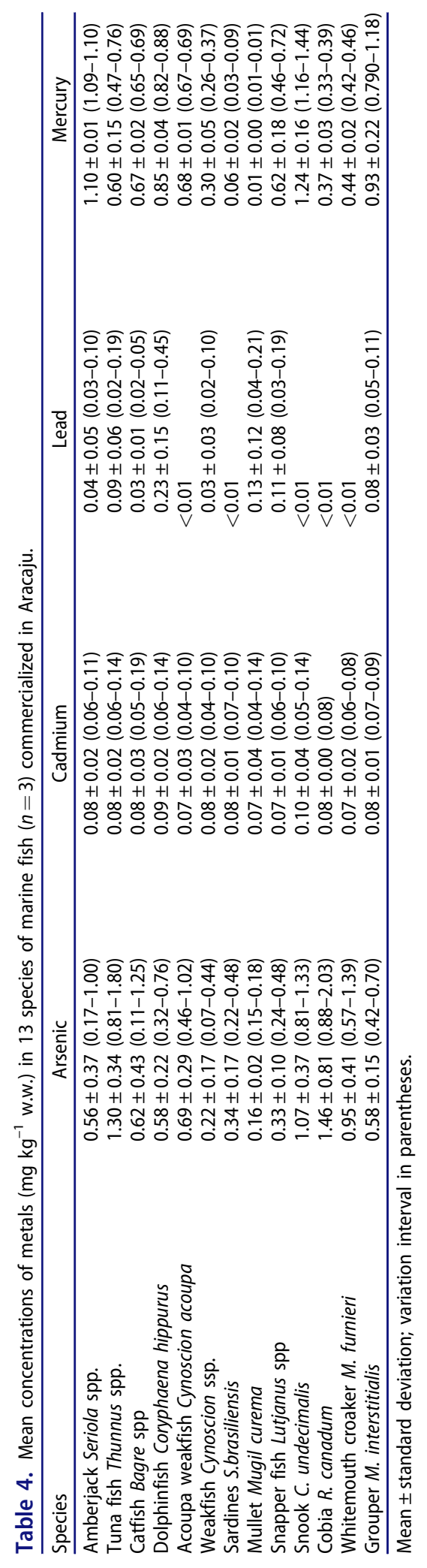


croaker-presented some specimens with concentrations close to the MTL. The highest levels of As in this group of predators may be related to the carnivorous feeding habits (Table 1) that concentrate this element through the food chain. The high levels of As in tuna can be attributed to their piscivorous diet of pelagic plankton fish. Its prey feed on marine phytoplankton, which has the ability to accumulate inorganic arsenic and transform it into organic arsenic via methylation, which is then transferred to the tuna through the trophic chain (Eisler 1988; Li et al. 2003). Peshut et al. (2008) reported that total As analysis was not a good indicator for evaluating the toxicity of the element in humans, and emphasized the importance of quantifying the toxic inorganic fractions and nontoxic organic fractions. In speciation studies of fish tissues, Gao et al. (2018) and Ruelas-Inzunza et al. (2018) established that the nontoxic organic form arsenobetaine constituted around $90 \%$ of total arsenic in fish.

\section{Cadmium}

The lowest and the highest concentrations of cadmium measured in the fish were $0.04 \mathrm{mg} \mathrm{kg}^{-1}$ in the acoupa weakfish (C. acoupa) and weakfish (Cynoscion spp.), and $0.19 \mathrm{mg} \mathrm{kg}^{-1}$ in the catfish (Bagre spp.) and mullet (M. curema), respectively. The mean concentration of $\mathrm{Cd}$ in all fish in this study were $0.08 \pm 0.02 \mathrm{mg} \mathrm{kg}^{-1}$, lower than the mean values of $0.23 \mathrm{mg} \mathrm{kg}^{-1} \mathrm{Cd}$ for the Gulf of Mexico (Lewis et al. 2002), but higher than the values for Black Sea fish on the Bulgarian coast $\left(0.01 \mathrm{mg} \mathrm{kg}^{-1}\right)$ (Makedonski et al. 2017); South China Sea fish (0.02 $\left.\mathrm{mg} \mathrm{kg}^{-1}\right)$ ( $\mathrm{Gu}$ et al. 2015); Atlantic Sea fish $\left(0.02 \mathrm{mg} \mathrm{kg}^{-1}\right)$ (Chahid et al. 2014); Portuguese coast fishes $\left(0.005 \mathrm{mg} \mathrm{kg}^{-1}\right.$ ) (Afonso et al. 2013); and Central Adriatic Sea fish $\left(0.06 \pm 0.04 \mathrm{mg} \mathrm{kg}^{-1}\right)$ (Perugini et al. 2014). The mean levels of $\mathrm{Cd}$ in tuna fish, sardines, and mullet did not exceed the MTL of $0.10 \mathrm{mg} \mathrm{kg}^{-1}$ specified for these species. The others-amberjack, catfish, dolphinfish, weakfish, snapper fish, snook, cobia, whitemouth croaker, and grouper fish-presented average levels above the MTL of $0.05 \mathrm{mg} \mathrm{kg}^{-1}$ prescribed by Brazilian Legislation.

Medeiros et al. (2012) analyzed 11 fish species commercialized in the main market of the city of Niterói, RJ, Brazil, and detected levels of $\mathrm{Cd}$ between 0.002 and $0.500 \mathrm{mg} \mathrm{kg}^{-1}$. On the other hand, Morgano et al. (2011) found concentrations of Cd ranging from $<0.010$ to $0.287 \mathrm{mg} \mathrm{kg}^{-1}$ in weakfish (Macrodon ancylodon), mullet (Mugil liza), and sardine (S. brasiliensis) commercialized in São Paulo, SP, Brazil, similar to the mean concentration of $\mathrm{Cd}$ in tuna in this study $\left(0.08 \pm 0.02 \mathrm{mg} \mathrm{kg}{ }^{-1}\right)$. These concentrations are higher than in measured in Thunnus obesus $\left(0.043 \pm 0.006 \mathrm{mg} \mathrm{kg} \mathrm{kg}^{-1}\right)$ from South China Sea (Gu et al. 2017).

The mean Cd levels of $0.07 \pm 0.04 \mathrm{mg} \mathrm{kg}^{-1}$ in mullet (M. curema) obtained in this study were higher than those found in another species of mullet (M. cephalus) which averaged $0.012 \pm 0.002 \mathrm{mg} \mathrm{kg}^{-1}$, from South China Sea by Gu et al. (2015). Zaza et al. (2015) reported values of $\mathrm{Cd}$ from 0.03 to $0.11 \mathrm{mg} \mathrm{kg}^{-1}$ in fish collected from Eastern Central Atlantic fishing areas and Afonso et al. (2013) observed concentrations of $0.02 \mathrm{mg} \mathrm{kg}^{-1}$ in various Portugal coast fishes. Joyeux et al. (2004) analyzed fish from the bay of Vitória, ES, Brazil, and found values between 0.02 and $0.04 \mathrm{mg} \mathrm{kg}^{-1}$ in Mugil spp.--lower than the $0.04-0.14 \mathrm{mg} \mathrm{kg}^{-1}$ obtained for this species in this study. 
Similarly, cadmium content in this fish from the basin of São Francisco do Conde, BA, Brazil varied from 0.01 to $0.08 \mathrm{mg} \mathrm{kg}^{-1}$ (Santos et al. 2013).

\section{Lead}

The lowest and highest concentrations of lead observed in this study were below detection limits in acoupa weakfish, sardines, snook, cobia, and whitemouth croaker, and were $0.45 \mathrm{mg} \mathrm{kg}^{-1}$ in dolphinfish. The mean concentration of lead for all the fish in this study was $0.09 \pm 0.07 \mathrm{mg} \mathrm{kg}^{-1}$, higher than the $0.07 \pm 0.02 \mathrm{mg} \mathrm{kg}^{-1}$ reported by Lewis et al. (2002) for fish from the Gulf of Mexico, of $0.05 \mathrm{mg} \mathrm{kg}^{-1}$ by Chahid et al. (2014) for Atlantic Sea fish, of $0.04 \pm 0.02 \mathrm{mg} \mathrm{kg}^{-1}$ by Perugini et al. (2014) for Central Adriatic Sea fish, and by Guérin et al. (2011), who found $0.011 \pm 0.009 \mathrm{mg} \mathrm{kg}^{-1}$ in fish collected in a French market. Our values were also lower than the $0.36 \mathrm{mg} \mathrm{kg} \mathrm{kg}^{-1}$ observed by Gu et al. (2015) in South China Sea fish. The dolphinfish (C. hippurus) was the only species evaluated that showed levels of lead above the MTL set by Brazilian legislation $\left(0.30 \mathrm{mg} \mathrm{kg}^{-1}\right)$. The differences in $\mathrm{Pb}$ concentrations among species can be attributed to the type of food consumed and the differences in fish eating habits (Serrão et al. 2014). $\mathrm{Pb}$ concentrations similar to those found in this study were observed for 11 species of fish traded in Niterói, RJ, Brazil, which presented levels between 0.01 and $0.50 \mathrm{mg} \mathrm{kg}^{-1}$ (Medeiros et al. 2012), between 0.03 and $0.48 \mathrm{mg} \mathrm{kg}^{-1}$ in fish commercialized in São Paulo, SP, Brazil (Morgano et al. 2011), and from 0.09 to $0.40 \mathrm{mg} \mathrm{kg}^{-1}$ in samples of canned fish collected in markets from Turkey (Tuzen and Soylak 2007).

Guérin et al. (2011) reported average levels of lead from 0.024 to $0.047 \mathrm{mg} \mathrm{kg}^{-1}$ for sardine, higher than those obtained in this study, whereas Elnabris et al. (2013) found higher levels $\left(0.55 \pm 0.48 \mathrm{mg} \mathrm{kg}^{-1}\right)$ in whitemouth croaker commercialized in Palestine. On the other hand, Zaza et al. (2015) reported values from 0.05 to $0.17 \mathrm{mg} \mathrm{kg}^{-1}$ in fish collected from Eastern Central Atlantic fishing area. Burger and Gochfeld (2005) found levels above $0.2 \mathrm{mg} \mathrm{kg}^{-1}$ in tuna marketed in New Jersey, USA-higher than those obtained in this study.

Compared with other studies, the Pb levels of $0.13 \pm 0.12 \mathrm{mg} \mathrm{kg}^{-1}$ in the M. curema obtained in this study were lower than the $0.25 \pm 0.05 \mathrm{mg} \mathrm{kg}^{-1}$ reported for Mugil brasilienses from Baia de Todos os Santos, BA, Brazil (Santos et al. 2013) and the $0.17 \pm 0.09 \mathrm{mg} \mathrm{kg}^{-1}$ in mullet marketed in Palestine (Elnabris et al. 2013). A study by Silva et al. (2016) found values ranging from 0.019 to $0.022 \mathrm{mg} \mathrm{kg}^{-1}$ in sea bream (Archosargus rhomboidalis) and snapper (L. synagris) marketed in Salvador, BA, Brazil, while in the Mediterranean, Storelli et al. (2013) observed $\mathrm{Pb}$ concentrations ranging from 0.08 to $0.12 \mathrm{mg} \mathrm{kg}^{-1}$, considered safe for consumption.

\section{Mercury}

The lowest $\left(0.005 \mathrm{mg} \mathrm{kg}^{-1}\right)$ and highest $\left(1.440 \mathrm{mg} \mathrm{kg}^{-1}\right) \mathrm{Hg}$ concentrations were found in $M$. curema and C. undecimalis, respectively. The average concentration of mercury in planktivorous fish was $0.03 \pm 0.01 \mathrm{mg} \mathrm{kg}^{-1}$, whereas in the predator group, it was $0.71 \pm 0.07 \mathrm{mg} \mathrm{kg}^{-1}$. Hg levels in planktivorous species did not exceed the MTL of $0.5 \mathrm{mg} \mathrm{kg}^{-1}$ determined by Brazilian legislation (ANVISA 2013). The highest mercury 
Table 5. THQ values for fish consumption, for inorganic arsenic, cadmium, lead, and mercury, in Aracaju, Brazil.

\begin{tabular}{lccccc}
\hline Species & Inorganic arsenic $^{\mathrm{a}}$ & Cadmium & Lead & Mercury & $T \mathrm{TQ}^{\mathrm{b}}$ \\
\hline Amberjack & 0.10 & 0.04 & 0.00 & 1.13 & 1.27 \\
Tuna fish & 0.22 & 0.04 & 0.01 & 0.62 & 0.89 \\
Catfish & 0.10 & 0.04 & 0.00 & 0.69 & 0.83 \\
Dolphinfish & 0.10 & 0.05 & 0.03 & 0.87 & 1.05 \\
Acoupa weakfish & 0.12 & 0.03 & 0.00 & 0.70 & 0.85 \\
Weakfish & 0.03 & 0.04 & 0.00 & 0.31 & 0.38 \\
Sardines & 0.05 & 0.04 & 0.00 & 0.06 & 0.15 \\
Mullet & 0.03 & 0.03 & 0.02 & 0.00 & 0.08 \\
Snapper fish & 0.05 & 0.03 & 0.01 & 0.64 & 0.73 \\
Snook & 0.19 & 0.05 & 0.00 & 1.28 & 1.52 \\
Cobia & 0.26 & 0.04 & 0.00 & 0.38 & 0.68 \\
Whitemouth croaker & 0.15 & 0.03 & 0.00 & 0.45 & 0.63 \\
Grouper & 0.10 & 0.04 & 0.01 & 0.81 & 0.96 \\
\hline
\end{tabular}

Values above 1.00 indicate risk.

${ }^{a}$ The inorganic content constitutes $10 \%$ of the total As in fish, according to Liao and Ling (2003) and Lin et al. (2005).

${ }^{\mathrm{b}} T T H Q=T H Q A s+T H Q C d+T H Q P b+T H Q H g$.

level of $1.24 \pm 0.16 \mathrm{mg} \mathrm{kg}^{-1}$ was observed in C. undecimalis, a carnivorous species from the top of the chain that, in the adult phase, feeds preferentially on fish (De Sousa Pereira et al. 2015), contributing to an extensive biomagnification of Hg (Kehrig et al. 2017). The C. undecimalis and S. lalandi were the species that presented Hg levels above the MTL of $1.0 \mathrm{mg} \mathrm{kg}^{-1}$ specific for carnivorous fish (ANVISA 2013; Esposito et al. 2018). According to Storelli (2008) and Ahmad et al. (2015), carnivorous species that feed on the bottom, such as snook and amberjack, present a great tendency to incorporate more mercury than those that feed close to the surface, such as tuna fish. This is due to the higher availability of $\mathrm{Hg}$ at the water-sediment interface, caused by the continuous production of methylmercury in this system (Bratkič et al. 2017). Nonetheless, after Farrugia et al. (2015) a reduction in mercury toxicity is attained when fish present higher concentrations of selenium.

Compared to other studies, the average level of $\mathrm{Hg}$ in $\mathrm{S}$. brasiliensis $\left(0.06 \pm 0.02 \mathrm{mg} \mathrm{kg}^{-1}\right)$ in this study was similar to the mean of $0.053 \pm 0.003 \mathrm{mg} \mathrm{kg}^{-1}$ in Sardinella aurita marketed in São Paulo, SP, Brazil (Augelli et al. 2007). Our results were higher than the $0.019 \pm 0.011 \mathrm{mg} \mathrm{kg}^{-1}$ in sardine also commercialized in São Paulo, SP, Brazil (Morgano et al. 2011) and lower than the $0.130 \pm 0.045 \mathrm{mg} \mathrm{kg}^{-1}$ in sardine from Cabo Frio, RJ, Brazil (Silva et al. 2011), the $0.08 \pm 0.05 \mathrm{mg} \mathrm{kg}^{-1}$ in S. brasiliensis from Ilha Grande Bay, RJ, Brazil (Seixas et al. 2015). The mean concentration of $0.006 \pm 0.001 \mathrm{mg} \mathrm{kg} \mathrm{kg}^{-1}$ in. curema in this study was lower than the $0.012 \pm 0.007 \mathrm{mg} \mathrm{kg}^{-1}$ in M. liza marketed in São Paulo, SP, Brazil (Morgano et al. 2011) and the $0.015 \pm 0.001 \mathrm{mg} \mathrm{kg}^{-1}$ in mullet from Guanabara Bay, RJ, Brazil (Kehrig et al. 2002). Zaza et al. (2015) reported average $\mathrm{Hg}$ values of $0.082 \pm 0.026 \mathrm{mg} \mathrm{kg}^{-1}$ in Tilapia heudelotii collected from an Eastern Central Atlantic fishing area.

The mean level of $\mathrm{Hg}$ of $0.60 \pm 0.10 \mathrm{mg} \mathrm{kg}^{-1}$ in Thunnus spp. observed in this study is similar to the $0.66 \pm 0.10 \mathrm{mg} \mathrm{kg}^{-1}$ reported by Burger and Gochfeld (2005) in similar fish species marketed in New Jersey, USA. Our values were higher than the $0.35 \mathrm{mg} \mathrm{kg}^{-1}$ in tuna fish destined for the Italian market (Galimberti et al. 2016); the $0.31 \mathrm{mg} \mathrm{kg}^{-1}$ in tuna fish marketed in Sesimbra, Portugal (Cabañero et al. 2005); and the 0.14 to $0.21 \mathrm{mg} \mathrm{kg}^{-1}$ in yellowfin tuna (Thunnus albacares) caught in two different geographic sites in the eastern Pacific Ocean (Ordiano-Flores et al. 2011). These results 
express the importance of the trophic position, the quality and composition of the preferred natural food intake, and longevity in the process of bioaccumulation and biomagnification of $\mathrm{Hg}$, in the different species analyzed. The results obtained confirm that lower levels of mercury are generally observed in planktivorous fish than in carnivores (Kehrig et al. 2013; Ahmad et al. 2015; Galimberti et al. 2016).

\section{Risk assessment}

In any risk assessment of a population, realistic fish intake rates are required, in order to characterize the threat to human health (Watanabe et al. 2003). In this study, the fish intake or consumption rate was $36 \mathrm{~g}_{\text {inhabitant }}^{-1}$ day $^{-1}$ (as suggested by USEPA 1989), which corresponds to an apparent per capita consumption of $13.14 \mathrm{~kg}_{\text {inhabitant }}{ }^{-1}$ year $^{-1}$. This per capita consumption of fish is similar to that published by De Oliveira Sartori and Amancio (2012), of $12.8 \mathrm{~kg}_{\text {inhabitant }}^{-1}$ year $^{-1}$ for the population of the Northeast region of Brazil.

The evaluation of the levels of trace metals in locally consumed fish is the first step in evaluating the risk to the human population. In calculating the specific THQ for each element, associated with the consumption of fish, the average concentration of each metal in the fish muscle, which is the edible part, was considered. Table 5 presents the THQ values for the evaluation of the potential risks of arsenic, cadmium, lead, and mercury exposure, from the target species in the study.

\section{Arsenic}

The toxic effects of arsenic depend on the oxidation state, chemical species, exposure dose, solubility in biological media, and excretion rate. The chemical form is the main factor for determining the risks to human health, and inorganic arsenic is more toxic than the organic forms (ATSDR 2007; Santos et al. 2013). Arsenic forms vary greatly depending on the organism, environment, and geographic location (Maher et al. 2018). Because of this variability, the toxicity of arsenic to humans is not accurately assessed when risk analyses are limited to total arsenic, and it is necessary to determine the inorganic toxic and organic nontoxic fractions (ATSDR 2007). There is general consensus in the literature that about $85-90 \%$ of the arsenic in the edible parts of marine fish is organic arsenic (e.g., arsenobetaine) (USEPA 2003; Lin and Liao 2008). The THQ As values of Table 5 were calculated based on the estimated toxic inorganic fraction, assuming that the inorganic arsenic constitutes $10 \%$ of the total arsenic in fish, similar to the calculations performed by Liao and Ling (2003) and Lin et al. (2005).

The arsenic THQ values (THQ As) ranged from 0.03 to 0.26 in the fish commercialized in Aracaju (Table 5). None of the fish evaluated in this study had THQ $>1$, and hence this does not constitute a risk for Aracaju consumers.

The high $\mathrm{THQ}_{\mathrm{As}}$ values observed in cobia, tuna fish, and snook can be attributed to their higher trophic levels and piscivorous feeding habits, where the arsenic is transferred to the links succession of the trophic web (Gao et al. 2018). Sardine-the preferred prey of the tuna fish-presented higher arsenic content than the weakfish and mullet in our study, similar to the results reported by Morgano et al. (2011). Cobia had 
the highest $\mathrm{THQ}_{\mathrm{As}}$ value of 0.26 , which can be attributed to its benthic feeding habits, where these fishes are exposed to higher levels of sediment-associated contaminants than are pelagic fish (Storelli 2008; Perugini et al. 2014). When THQ is $<1$, there is no potential risk of harm to human health (USEPA 1989).

\section{Cadmium}

The health implications of cadmium exposure are worsened by the relative inability of humans to excrete cadmium. Acute $\mathrm{Cd}$ poisoning is characterized by fever, irritation of the eyes, nose and throat, cough, dyspnea, weakness, nausea, vomiting, abdominal cramps, and diarrhea, and may cause acute lung edema ( $\mathrm{Gu}$ et al. 2017). Chronic exposure causes respiratory problems, dental cavities, yellowing of teeth, anorexia, fatigue, weight loss, pallor, anemia, proteinuria, and renal tubular damage (Godt et al. 2006; Dural et al. 2007). The cadmium THQ values (THQ $\mathrm{Cd}$ ) in the fish commercialized in Aracaju varied from 0.03 to 0.05 (Table 5), and the mean value of $\mathrm{THQ}_{\mathrm{Cd}}$ was $0.04 \pm 0.01$ higher than the $0.02 \pm 0.01$ found by Gu et al. (2015). Storelli (2008) obtained $\mathrm{THQ}_{\mathrm{Cd}}$ values between 0.01 and 0.04 for 18 marine fish species: ranges similar to those obtained in this study. The highest THQ $\mathrm{Cd}$ of 0.05 was found in dolphinfish and snook, and all the $\mathrm{THQ}_{\mathrm{Cd}}$ values for cadmium in this study were far $<1$, similar to those obtained by $\mathrm{Gu}$ et al. (2015) for four fish species from the South China Sea.

\section{Lead}

The adverse effects caused by the accumulation of lead in organisms are neurological damage and renal diseases, as well as cardiovascular and reproductive impairments (Alessio et al. 2007). The inorganic form is the most frequent, as well as the most toxic and most easily absorbed by organisms (Garza et al. 2006).

The values of the lead THQs (THQ $\mathrm{Pb}$ ) ranged from 0.00 to 0.03 , and were similar to those measured by Storelli (2008) (between 0.002 and 0.180 ), and the mean value of $0.01 \pm 0.01$ was lower than that calculated by $\mathrm{Gu}$ et al. (2015) $(0.02 \pm 0.01)$ in the fish of the South China Sea. The highest value of $\mathrm{THQ}_{\mathrm{Pb}}-0.03$-was observed in the dolphinfish.

The THQs of lead and cadmium (Table 5) presented values $<1$ for all the target species in the study, and do not represent a risk to consumers of these fish. These results corroborate those obtained by Vieira et al. (2011) in fish commercialized in Porto, Portugal, who reported an absence of adverse effects on human health due to the levels of lead and cadmium found in the evaluated fish. Similar results were reported by Watanabe et al. (2003), who used other risk indicators and determined that cadmium and lead did not present any appreciable risk, although in their study, arsenic did show potential risk via fish consumption.

\section{Mercury}

The principal dietary source of neurotoxic mercury compounds is the ingestion of species of fish in which methylmercury has accumulated (González-Estecha et al. 2014). 
Methylmercury from fish has been linked to neurological damage (Minamata disease) (Hong et al. 2012), adverse neurodevelopmental (Myers et al. 2009), cardiovascular (Grandjean et al. 2004), and immunological health effects (Gardner et al. 2010). The mercury THQ values $\left(\mathrm{THQ}_{\mathrm{Hg}}\right.$ ) in this study ranged from 0.00 to 1.28 , and the highest value was observed in C. undecimalis, followed by Seriola spp. (1.13), indicating potential risk to human health. The interval of variation in $\mathrm{THQ}_{\mathrm{Hg}}$ observed in this study was similar to those reported by Storelli (2008) in European anchovy Engraulis encrasicholus and albacore Thunnus alalunga (from 0.08 to 1.87). On other hand, $\mathrm{THQ}_{\mathrm{Hg}}$ was $<1$ in yellowfin tuna (Thunnus albacares) caught in the eastern Pacific Ocean (Ordiano-Flores et al. 2011) and was 0.21 in sharks from the Persian Gulf (Adel et al. 2016).

Two species of predatory fish, Coryphaena hippurus (0.87) and Mycteroperca interstitialis (0.81), presented $\mathrm{THQ}_{\mathrm{Hg}}$ values close to 1 , and the lowest values were observed in M. curema and S. brasiliensis (Table 5). These data corroborate Storelli (2008), who indicated a lower potential risk of consumption based on THQ in species at the base of the food chain than in predators at the top.

\section{TTHQ}

Some contaminants may have a synergistic effect when present in the same tissues and consumed together. Thus, Total Target Hazard Quotient (TTHQ) represents the simple sum of each specific THQ for each metal (Eq. (2)) as proposed by Chien et al. (2002):

$$
T T H Q=T H Q_{\mathrm{As}}+T H Q_{\mathrm{Cd}}+T H Q_{\mathrm{Pb}}+T H Q_{\mathrm{Hg}}
$$

The lowest and highest values of TTHQ were 0.08 in mullet and 1.52 in snook. The mean value of TTHQ was $0.77 \pm 0.41$ higher than the 0.64 calculated by Saha et al. (2016), the 0.35 found by Adel et al. (2016), and the 0.05 found by $\mathrm{Gu}$ et al. (2015), without considering the contribution of the risk associated with mercury. Storelli (2008), considering THQ relative to Hg, recorded a TTHQ $>1$ in albacore Thunnus alalunga (2.08), rosefish Helicolenus dactylopterus (1.54), and thornback ray Raja clavata (1.06). The fish in this study that presented a potential risk to the human health based on TTHQ $>1$ were amberjack, dolphinfish, and snook (Table 5).

\section{Conclusions}

The levels of lead in the muscle of the target species presented acceptable toxicological levels for human consumption, except for dolphinfish, which presented samples that exceeded the MTL established by Brazilian Legislation. Regarding the cadmium levels, only tuna fish, sardines, and mullet did not exceed the MTL; however, based on THQ, none of the evaluated fish presented a risk to the consumer.

Tuna fish, snook, and cobia presented total arsenic levels above MTL, but none of the species evaluated had THQ $>1$, calculated based on estimated inorganic arsenic, and did not represent a potential risk to human health. Speciation for arsenic compounds is necessary to determine the organic (nontoxic) and inorganic (toxic) forms in the fish and to enable more accurate risk assessments. In addition, it is fundamental that Brazilian legislation establishes the maximum limits of inorganic arsenic levels in the different fish species. 
Snook and amberjack presented total mercury contents above the MTL, and grouper presented values very close to this limit. The mean concentrations of total mercury were lower in the fish at the base of the food chain and increased toward higher trophic levels. The need for speciation is relevant especially when, as in the specific cases of mercury and arsenic, the chemical forms demonstrate different impacts and behaviors such as toxicity, mobility and bioavailability.

The THQ estimate used in this study was sensitive enough to detect differences in potential human health risk, within the fish species and metals evaluated. TTHQ values $>1$, in descending order, accounted for: snook $>$ amberjack $>$ dolphinfish. These fish should be moderately consumed because of the potential human health risk caused by the evaluated metals. The reassessment of target species in future years is important to verify whether there is a change in the potential consumption risk for these species.

Knowledge about the potential risk of consumption of fish that may present arsenic, cadmium, lead, or mercury levels above the MTL is of major importance for health surveillance agencies, so that they can develop recommendations of safe levels of consumption of target species, in particular for children, pregnant women, and nursing mothers.

\section{Funding}

This study was supported by the Brazilian Council of Scientific and Technological Development [grant number 481925/2013-9]; the Foundation for the Support to the Research and Technological Innovation of the State of Sergipe; granted a Junior Research scholarship to SOS; the Foundation Carlos Chagas Filho for the Support to the Research of the State of Rio de Janeiro granted a Junior Research Scholarship to GCdP [grant number 216606]; the Brazilian Council of Scientific and Technological Development granted a research fellowship to JCW [grant number 306714/2013-2].

\section{References}

Adel M, Conti GO, Dadar M, et al. 2016. Heavy metal concentrations in edible muscle of whitecheek shark, Carcharhinus dussumieri (elasmobranchii, chondrichthyes) from the Persian Gulf: a food safety issue. Food Chem Toxicol 97:135-40.

Afonso C, Cardoso C, Lourenço HM, et al. 2013. Evaluation of hazards and benefits associated with the consumption of six fish species from the Portuguese coast. J Food Compos Anal 32: 59-67.

Ahmad NI, Noh MFM, Mahiyuddin WRW, et al. 2015. Mercury levels of marine fish commonly consumed in Peninsular Malaysia. Environ Sci Pollut Res 22:3672-86.

Alessio L, Campagna M, and Lucchini R. 2007. From lead to manganese through mercury: Mythology, science, and lessons for prevention. Am J Ind Med 50:779-87.

Anonymous. 2004. O mercado de pescado de Aracaju (The fish market in Aracaju, Brazil). INFOPESCA/INFOFISH 45.

ANVISA. 2013. Limites máximos de contaminantes inorgânicos em alimentos. In: Sanitária ANdV (ed), vol Resolução 49. Diário Oficial da República do Brasil, Brasília

ATSDR. 2007. Toxicological profile for arsenic. Agency for Toxic Substances and Disease Registry, Division of Toxicology, Atlanta, GA, vol 2016, pp. 500.

Augelli M, Munoz R, Richter E, et al. 2007. Analytical procedure for total mercury determination in fishes and shrimps by chronopotentiometric stripping analysis at gold film electrodes after microwave digestion. Food Chem 101:579-84. 
Avigliano E, Lozano C, Plá RR, et al. 2016. Toxic element determination in fish from Paraná River Delta (Argentina) by neutron activation analysis: Tissue distribution and accumulation and health risk assessment by direct consumption. J Food Compos Anal 54:27-36.

Berk M, Williams LJ, Andreazza AC, et al. 2014. Pop, heavy metal and the blues: Secondary analysis of persistent organic pollutants (POP), heavy metals and depressive symptoms in the NHANES National Epidemiological Survey. BMJ Open 4:1-9.

Bosch AC, O’Neill B, Sigge GO, et al. 2016. Heavy metals in marine fish meat and consumer health: A review. J Sci Food Agric 96:32-48.

Brasil. 2011. Boletim estatístico da pesca e aquicultura 2011. vol 2016. Ministério da pesca e aquicultura Brasília.

Bratkič A, Koron N, Ribeiro Guevara S, et al. 2017. Seasonal variation of mercury methylation potential in pristine coastal marine sediment from the Gulf of Trieste (Northern Adriatic Sea). Geomicrobiol J 34:587-95.

Burger J and Gochfeld M 2005. Heavy metals in commercial fish in New Jersey. Environ Res 99: 403-12.

Burger J, Gochfeld M, Batang Z, et al. 2014. Interspecific and locational differences in metal levels in edible fish tissue from Saudi Arabia. Environ Monit Assess 186:6721-46.

Cabañero AI, Carvalho C, Madrid Y, et al. 2005. Quantification and speciation of mercury and selenium in fish samples of high consumption in Spain and Portugal. Biol Trace Elem Res 103: $17-35$.

Castro-González M and Méndez-Armenta M 2008. Heavy metals: Implications associated to fish consumption. Environ Toxicol Pharmacol 26:263-71.

Chahid A, Hilali M, Benlhachimi A, et al. 2014. Contents of cadmium, mercury and lead in fish from the Atlantic sea (Morocco) determined by atomic absorption spectrometry. Food Chem 147:357-60.

Chien L-C, Hung T-C, Choang K-Y, et al. 2002. Daily intake of TBT, Cu, Zn, Cd and As for fishermen in Taiwan. Sci Tot Environ 285:177-85.

CTA. 2013. Metais em peixes: páscoa em alerta: arsênio encontrado. Rio de Janeiro, RJ.

de Oliveira Sartori AG and Amancio RD. 2012. Pescado: importância nutricional e consumo no Brasil. Segurança alimentar e nutricional 19:83-93.

de Sousa Pereira MEG, da Silva BB, da Rocha RM, et al. 2015. Bioecologia do robalo-flexa, Centropomus undecimalis, em lagoa costeira tropical no norte do Brasil. Boletim do Instituto de Pesca 41:457-69.

Dural M, Göksu MZL, and Özak AA. 2007. Investigation of heavy metal levels in economically important fish species captured from the Tuzla lagoon. Food Chem 102:415-21.

Eisler R. 1988. Arsenic hazards to fish, wildlife, and invertebrates: A synoptic review. Fish and Wildlife Service, US Department of the Interior.

Elnabris KJ, Muzyed SK, and El-Ashgar NM. 2013. Heavy metal concentrations in some commercially important fishes and their contribution to heavy metals exposure in Palestinian people of Gaza Strip (Palestine). J Assoc Arab Univ Basic Appl Sci 13:44-51.

Esposito M, De Roma A, La Nucara R, et al. 2018. Total mercury content in commercial swordfish (Xiphias gladius) from different FAO fishing areas. Chemosphere 197:14-9.

Fallah AA, Saei-Dehkordi SS, Nematollahi A, et al. 2011. Comparative study of heavy metal and trace element accumulation in edible tissues of farmed and wild rainbow trout (Oncorhynchus mykiss) using ICP-OES technique. Microchem J 98:275-9.

FAO. 2016. The State of the World Fisheries and Aquaculture (SOFIA) 2016. Contributing to food security and nutrition for all. Rome.

Farrugia TJ, Oliveira ACM, Knue JF, et al. 2015. Nutritional content, mercury, and trace element analyses of two skate (Rajidae) species in the Gulf of Alaska. J Food Compos Anal 42:152-63.

Galimberti C, Corti I, Cressoni M, et al. 2016. Evaluation of mercury, cadmium and lead levels in fish and fishery products imported by air in North Italy from extra-European Union Countries. Food Control 60:329-37. 
Gao Y, Baisch P, Mirlean N, et al. 2018. Arsenic speciation in fish and shellfish from the North Sea (Southern bight) and Açu Port area (Brazil) and health risks related to seafood consumption. Chemosphere 191:89-96.

Gardner RM, Nyland JF, Silva IA, et al. 2010. Mercury exposure, serum antinuclear/antinucleolar antibodies, and serum cytokine levels in mining populations in Amazonian Brazil: A cross-sectional study. Environ Res 110:345-54.

Garza A, Vega R, and Soto E. 2006. Cellular mechanisms of lead neurotoxicity. Med Sci Monit 12:RA57-65.

Godt J, Scheidig F, Grosse-Siestrup C, et al. 2006. The toxicity of cadmium and resulting hazards for human health. J Occup Med Toxicol 1:22.

González-Estecha M, Bodas-Pinedo A, Rubio-Herrera MÁ, et al. 2014. The effects of methylmercury on health in children and adults; national and international studies. Nutr Hosp 30: 989-1007.

Grandjean P, Murata K, Budtz-Jørgensen E, et al. 2004. Cardiac autonomic activity in methylmercury neurotoxicity: 14-year follow-up of a Faroese birth cohort. J Pediatr 144:169-76.

Gu Y-G, Lin Q, Huang H-H, et al. 2017. Heavy metals in fish tissues/stomach contents in four marine wild commercially valuable fish species from the western continental shelf of South China Sea. Mar Pollut Bull 114:1125-9.

Gu Y-G, Lin Q, Wang X-H, et al. 2015. Heavy metal concentrations in wild fishes captured from the South China Sea and associated health risks. Mar Pollut Bull 96:508-12.

Guérin T, Chekri R, Vastel C, et al. 2011. Determination of 20 trace elements in fish and other seafood from the French market. Food Chem 127:934-42.

Guil-Guerrero JL, Venegas-Venegas E, Rincón-Cervera MÁ, et al. 2011. Fatty acid profiles of livers from selected marine fish species. J Food Compos Anal 24:217-22.

Guo B, Jiao D, Wang J, et al. 2016. Trophic transfer of toxic elements in the estuarine invertebrate and fish food web of Daliao River, Liaodong Bay, China. Mar Pollut Bull 113:258-65.

Hatch WR and Ott WL. 1968. Determination of submicrogram quantities of mercury by atomic absorption spectrophotometry. Anal Chem 40:2085-7.

He K. 2009. Fish, long-chain Omega-3 polyunsaturated fatty acids and prevention of cardiovascular disease-Eat fish or take fish oil supplement? Prog Cardiovasc Dis 52:95-114.

Hight SC and Cheng J. 2005. Determination of total mercury in seafood by cold vapor-atomic absorption spectroscopy (CVAAS) after microwave decomposition. Food Chem 91:557-70.

Hong Y-S, Kim Y-M, and Lee K-E. 2012. Methylmercury exposure and health effects. J Prevent Med Public Health 45:353.

Jarić I, Višnjić-Jeftić Ž, Cvijanović G, et al. 2011. Determination of differential heavy metal and trace element accumulation in liver, gills, intestine and muscle of sterlet (Acipenser ruthenus) from the Danube River in Serbia by ICP-OES. Microchem J 98:77-81.

Joyeux J-C, Campanha Filho EA, and Jesus HCd. 2004. Trace metal contamination in estuarine fishes from Vitória Bay, ES, Brazil. Braz Arch Biol Technol 47:765-74.

Jureša D and Blanuša M 2003. Mercury, arsenic, lead and cadmium in fish and shellfish from the Adriatic Sea. Food Addit Contam 20:241-6.

Kehrig H, Costa M, Moreira I, et al. 2002. Total and methylmercury in a Brazilian estuary, Rio de Janeiro. Mar Pollut Bull 44:1018-23.

Kehrig HA, Baptista G, Di Beneditto APM, et al. 2017. Biomagnificación de mercurio en la cadena trófica del Delfín Moteado del Atlántico(Stenella frontalis), usando el isótopo estable de nitrógeno como marcador ecológico. Revista de biología marina y oceanografía 52:233-44.

Kehrig HA, Seixas TG, Di Beneditto APM, et al. 2013. Selenium and mercury in widely consumed seafood from South Atlantic Ocean. Ecotoxicol Environ Saf 93:156-62.

Lewis MA, Scott GI, Bearden DW, et al. 2002. Fish tissue quality in near-coastal areas of the Gulf of Mexico receiving point source discharges. Sci Tot Environ 284:249-61.

Li W, Wei C, Zhang C, et al. 2003. A survey of arsenic species in Chinese seafood. Food Chem Toxicol 41:1103-10. 
Liao C and Ling M 2003. Assessment of human health risks for arsenic bioaccumulation in tilapia (Oreochromis mossambicus) and large-scale mullet (Liza macrolepis) from blackfoot disease area in Taiwan. Arch Environ Contam Toxicol 45:264-72.

Lin M and Liao C 2008. Assessing the risks on human health associated with inorganic arsenic intake from groundwater-cultured milkfish in southwestern Taiwan. Food Chem Toxicol 46: 701-9.

Lin M-C, Lin H-Y, Cheng H-H, et al. 2005. Risk assessment of arsenic exposure from consumption of cultured milkfish, Chanos chanos (Forsskål), from the arsenic-contaminated area in southwestern Taiwan. Bull Environ Contam Toxicol 75:637-44.

Maher W, Waring J, Krikowa F, et al. 2018. Ecological factors affecting the accumulation and speciation of arsenic in twelve Australian coastal Bivalve molluscs. Environ Chem 15:46-57.

Makedonski L, Peycheva K, and Stancheva M 2017. Determination of heavy metals in selected black sea fish species. Food Control 72:313-8.

Mathews T and Fisher NS 2008. Trophic transfer of seven trace metals in a four-step marine food chain. Mar Ecol Prog Ser 367:23-33.

Mathews T and Fisher NS 2009. Dominance of dietary intake of metals in marine elasmobranch and teleost fish. Sci Tot Environ 407:5156-61.

Medeiros RJ, dos Santos LMG, Freire AS, et al. 2012. Determination of inorganic trace elements in edible marine fish from Rio de Janeiro State, Brazil. Food Control 23:535-41.

Morgano MA, Oliveira APFd, Rabonato LC, et al. 2011. Avaliação de contaminantes inorgânicos (As, $\mathrm{Cd}, \mathrm{Cr}, \mathrm{Hg}$ e $\mathrm{Pb}$ ) em espécies de peixes. Revista do Instituto Adolfo Lutz (Impresso) 70: 497-506.

Myers GJ, Thurston SW, Pearson AT, et al. 2009. Postnatal exposure to methyl mercury from fish consumption: a review and new data from the Seychelles Child Development Study. Neurotoxicology 30:338-49.

Ordiano-Flores A, Galván-Magaña F, and Rosiles-Martínez R 2011. Bioaccumulation of mercury in muscle tissue of yellowfin tuna, Thunnus albacares, of the eastern Pacific Ocean. Biol Trace Elem Res 144:606-20

Perugini M, Visciano P, Manera M, et al. 2014. Heavy metal (As, Cd, Hg, Pb, Cu, Zn, Se) concentrations in muscle and bone of four commercial fish caught in the central Adriatic Sea, Italy. Environ Monit Assess 186:2205-13.

Peshut PJ, Morrison RJ, and Brooks BA 2008. Arsenic speciation in marine fish and shellfish from American Samoa. Chemosphere 71:484-92.

Pohlenz C and Gatlin DM 2014. Interrelationships between fish nutrition and health. Aquaculture 431:111-7

Rainbow PS 2007. Trace metal bioaccumulation: Models, metabolic availability and toxicity. Environ Int 33:576-82.

Ruelas-Inzunza J, Slejkovec Z, Mazej D, et al. 2018. Bioaccumulation of As, Hg, and Se in tunas Thunnus albacares and Katsuwonus pelamis from the Eastern Pacific: Tissue distribution and As speciation. Environ Sci Pollut Res Int 25:19499-509.

Saha N, Mollah M, Alam M, et al. 2016. Seasonal investigation of heavy metals in marine fishes captured from the Bay of Bengal and the implications for human health risk assessment. Food Control 70:110-8.

Santos LFP, Trigueiro INS, Lemos VA, et al. 2013. Assessment of cadmium and lead in commercially important seafood from São Francisco do Conde, Bahia, Brazil. Food Control 33:193-9.

Schneider L, Maher WA, Potts J, et al. 2018. Trophic transfer of metals in a seagrass food web: Bioaccumulation of essential and non-essential metals. Mar Pollut Bull 131:468-80.

Seixas TG, Moreira I, and Kehrig HA 2015. Mercury and selenium in seston, marine plankton and fish (Sardinella brasiliensis) as a tool for understanding a tropical food web. Mar Pollut Bull 101:366-9.

Serrão CRG, Pontes AN, Kelly das Graças FD, et al. 2014. Biomonitoramento de Elementos Metálicos em Peixes de Água Doce da Região Amazônica. Revista Virtual de Química 6: 1661-76. 
Silva CAd, Tessier E, Kütter VT, et al. 2011. Mercury speciation in fish of the Cabo Frio upwelling region, SE-Brazil. Braz J Oceanogr 59:259-66.

Silva E, Costa FN, Souza TL, et al. 2016. Assessment of trace elements in tissues of fish species: Multivariate study and safety evaluation. J Braz Chem Soc 27:2234-45.

Storelli M 2008. Potential human health risks from metals ( $\mathrm{Hg}, \mathrm{Cd}$, and $\mathrm{Pb}$ ) and polychlorinated biphenyls (PCBs) via seafood consumption: Estimation of target hazard quotients (THQs) and toxic equivalents (TEQs). Food Chem Toxicol 46:2782-8.

Storelli MM, Barone G, Perrone VG, et al. 2013. Risk characterization for polycyclic aromatic hydrocarbons and toxic metals associated with fish consumption. J Food Compos Anal 31: $115-9$.

Tuzen M and Soylak M 2007. Determination of trace metals in canned fish marketed in Turkey. Food Chem 101:1378-82.

USEPA. 1989. Assessing human health risks from chemically contaminated, fish and shellfish: A guidance manual. In: Agency USEP (ed), EPA Office of Marine and Estuarine Protection, p. 174. Washington, DC.

USEPA. 2003. Technical Summary of Information Available on the Bioaccumulation of Arsenic in Aquatic Organisms. Washington, DC.

USEPA. 2010. Risk-Based Concentration Table. Washington, DC.

Vieira C, Morais S, Ramos S, et al. 2011. Mercury, cadmium, lead and arsenic levels in three pelagic fish species from the Atlantic Ocean: Intra- and inter-specific variability and human health risks for consumption. Food Chem. Toxicol 49:923-32.

Watanabe KH, Desimone FW, Thiyagarajah A, et al. 2003. Fish tissue quality in the lower Mississippi River and health risks from fish consumption. Sci Total Environ 302:109-26.

Yañez LM, Alfaro JA, and Bovi Mitre G. 2018. Absorption of arsenic from soil and water by two chard (Beta vulgaris L.) varieties: A potential risk to human health. J Environ Manag 218: 23-30.

Yi Y, Yang Z, and Zhang S. 2011. Ecological risk assessment of heavy metals in sediment and human health risk assessment of heavy metals in fishes in the middle and lower reaches of the Yangtze River basin. Environ Pollut 159:2575-85.

Zaza S, de Balogh K, Palmery M, et al. 2015. Human exposure in Italy to lead, cadmium and mercury through fish and seafood product consumption from Eastern Central Atlantic Fishing Area. J Food Compos Anal 40:148-53.

Zhao R, Yan S, Liu M, et al. 2016. Seafood consumption among Chinese coastal residents and health risk assessment of heavy metals in seafood. Environ Sci Pollut Res Int 23:16834-44.

Zhu F, Fan W, Wang X, et al. 2011. Health risk assessment of eight heavy metals in nine varieties of edible vegetable oils consumed in China. Food Chem Toxicol 49:3081-5. 